ThE WILLIAM DAVIDSON INSTITUTE

AT THE UNIVERSITY OF MICHIGAN

\title{
ONCE BITTEN, TWICE SHY: EXPERIENCES OF A BANKING CRISIS AND EXPECTATIONS OF FUTURE CRISES
}

\author{
By: Shannon Mudd \& Neven Valev
}

William Davidson Institute Working Paper Number 969

September 2009 


\title{
ONCE BITTEN, TWICE SHY: \\ EXPERIENCES OF A BANKING CRISIS AND EXPECTATIONS OF FUTURE CRISES
}

by

Shannon Mudd

Ursinus College

\author{
Neven Valev \\ Georgia State University
}

\begin{abstract}
Survey data from Bulgaria show that people who had experienced a loss during a banking crisis are significantly more likely to expect a new crisis. This result holds despite 12 years between the earlier crisis and the survey, and the dramatically improved performance of the financial sector and the economy in the meantime. However, we find that earlier experiences affect expectations only for less informed individuals. Individuals who are more informed about the economy are unaffected by their prior experiences.
\end{abstract}

JEL classification: G2; D8

Keywords: banking crisis, trust, expectations

We would like to thank Klara Peter, Fernando Rios, Erdal Tekin, Andrew Economopoulos and the participants at the Tri-College Economics Seminar at Swarthmore for helpful comments. We would also like to thank the National Council for Eurasia and East European Research (NCEEER) for their generous financial support and for additional funding through the Pearlstine Fellows Program at Ursinus College. Mudd: Department of Business and Economics, Ursinus College, Collegeville, PA 19426, tel.601-409-3000, e-mail: smudd@ursinus.edu; Valev: Department of Economics, Georgia State University, Atlanta, GA 30030; tel. 404-413-0162, e-mail: nvalev@gsu.edu. 


\section{Introduction}

The first and foremost promise made by banks to depositors is to keep their money safe, a promise that has generally been kept, building trust and enabling financial intermediation to flourish across countries. However, this promise has been breached on occasion during some banking crises resulting in the loss of depositor savings. After such a loss, how long does it take for people to regain confidence in banks? It is human nature to forget. If memories are short, the period needed to revive trust in banks may be only a few years. People might also believe that the crisis was a fluke or that it reflected economic conditions that are no longer at play. Again, trust could be regained fairly rapidly. However, it is also possible that the crisis permanently enters people's beliefs about the operations of an economy and how it can go wrong. After all, if it happened once, what can guarantee it will not happen again?

We provide evidence on the effect of an earlier banking crisis on future expectations using unique survey data from Bulgaria. Bulgaria's banking system imploded in 1996, midway through its transition from communism. Many people lost much of their savings. Twelve years later, in 2008, a national household survey asked respondents about the likelihood of a banking crisis during the next months or years. It also inquired about peoples' experiences during the crisis in 1996. These two questions allow us to test how prior experiences with a banking crisis condition expectations of another crisis.

We find that people who lost money in 1996 were significantly more likely to expect a new crisis. This result is robust to the inclusion of a number of control variables, to corrections for reverse causality and measurement error, to various definitions of the dependent and key independent variables, and to various econometric methods. Given the length of time and more recent, sustained stability and growth in the Bulgarian economy, this persistent effect of a past negative experience on current expectations indicates how difficult it is to regain trust in the financial sector. ${ }^{1}$

Our findings also indicate that there is heterogeneity in the influence of past experience across different individuals. We find that prior experiences are more influential on the

\footnotetext{
${ }^{1}$ A recent advertising leaflet by a Bulgarian bank illustrates the problem of incomplete trust facing banks. The top half of the page features photos of a jar filled with sugar, a mattress, a pair of shoes, a shelf with books, and several other places where people usually hide cash. The message below the photos reads: "If we know where you keep the money, they also know"; "they" are, of course, the thieves. The implicit message is to deposit the money in the bank instead. This campaign would not be necessary if people believed that bank deposits were risk free.
} 
expectations of those individuals who are less informed about the economy. In contrast, the expectations of more informed people are unaffected by their experiences during the 1996 crisis. That result is consistent with models of heterogeneous agents such as Haltiwanger and Waldman (1985) which question the assumption of full rational expectations across all individuals. For some individuals in a new, changed economic environment, past events from a very different economic system do not influence expectations, a result consistent with rational expectations. However, other individuals continue to look backwards and appear not to go through the process of assessing the new conditions.

The paper makes contributions to three broad strands of the literature. First, it provides direct evidence, on the micro level, that crises affect expectations for a long time. Studying the Great Depression, Cagan (1965) modeled the expectations of the future rate of loss on deposits as depending on some average of the past experience of losses. Calvo's (1986) paper on "temporary stabilizations" builds on a similar idea in the context of currency crises: in countries with a history of crises, economic agents do not expect stabilizations to be permanent. The hysteresis of currency substitution, i.e. that dollarization increases during high inflation but does not decline once inflation has declined, has also been explained by persistent expectations of renewed instability, e.g. Melvin and Fenske (1992). In short, the notion that crises have lasting effects on expectations is in the literature. However, to our knowledge, the results presented here are the first direct evidence on this effect.

Second, the paper contributes to the literature on trust and financial development. Guiso, Sapienza and Zingales (2004), Knack and Keefer (1997) and others show that trust and social capital are essential determinants of financial development. Yet, little is known about the determinants of trust. Our results make a contribution in this regard, showing that a banking crisis can reduce confidence for over a decade.

The third contribution is that the paper shows evidence for a strong backward-looking component in the formation of expectations and for substantial variation in the effect of past experiences on expectations across the population. The process of expectations formation is central to economics and continues to attract significant research interest, e.g. Sargent (1982) and Branch (2004). The heterogeneity in terms of information endowments and expectations formation has also been studied extensively, e.g. Haltiwanger and Waldman (1985) and Mankiw and Reis (2002). These are, of course, large issues that cannot be settled with our data. Yet, we 
are able to assess the effect of one important potential influence on expectations - a sweeping banking crisis. Understanding how banking crises affect expectations is important for policymakers seeking to convince a population that new economic policy reforms have moved the economy to a new structure immune from past problems.

The rest of the paper is structured as follows. The following section presents brief background notes on Bulgaria's banking and currency crisis in 1996 as well as information on economic performance since that time. The next section includes the basic theoretical construct of our question on expectations formation and the influence of past events. We then describe the survey instrument before leading into the regression model and the estimation results. Finally we offer some concluding comments.

\section{The 1996 Financial Crisis in Bulgaria}

Bulgaria experienced one of the sharpest financial crises in Eastern Europe during its transition from socialism. During the banking crisis in 1996 and the first months of 1997 , 56.3 percent of the loans on the books of state-owned banks were classified as "non-standard", i.e. loans with payment delays or outright defaults. Even worse, 66.7 percent of the loans of smaller privately owned banks were non-standard (BNB, 1996). Throughout 1996, the government attempted to assist banks by infusing large amounts of government funds but, eventually, a number of banks collapsed and the infusion of money into the financial system set off inflation. Berlemann, Hristov, and Nenovsky (2002) detail how the crisis unfolded and the government response:

"Chronologically, the first wave of the crisis came from the banking system when in the end of May 1996 BNB [The Bulgarian Central Bank] took 5 commercial banks, 3 of which were private, under conservatorship. The attack on the banks was triggered by depositors' expectations that their foreign deposits would be confiscated or frozen by the government in order to allow it to meet its interest payments on the external debt due in July (there were several indications that the government could do so). The fact that Bulgaria had no agreement with the International Monetary Fund (IMF) in 1996 reinforced this fear. The deposits from the bankrupt banks were transferred to the sound ones and at the same time a Law for Bank Deposit Guarantee passed the Parliament. According to this law the government had to repay the full amounts of individuals' deposits with bankrupt banks and 50 percent of enterprises' deposits. At first, individuals were allowed to draw their deposits in BGN [the domestic money] before the court declared its decision on closed banks (withdrawals of foreign currency deposits were in portions). The money withdrawn was quickly directed to the foreign currency market 
where BGN got under pressure. Later on, this permission was abolished and BGN deposits were also blocked. Altogether, throughout 1996 depositors lost more than 50 percent of their savings. ${ }^{2}$

The financial crisis had been building for some time as Bulgaria was slow in reforming its real economy (see Berlemann, Hristov, and Nenovsky 2002 and Dobrinsky 2000). Both stateowned banks and many private banks channeled funds to inefficient state-owned enterprises the government considered too important to liquidate. Credits to these firms often served merely as stop-gap efforts either to cover losses or service existing loans. While the infusion of funds enabled them to continue to operate, eventually these firms could no longer service their debts. In the meantime, the liberalization of financial markets and the lax supervision resulted in the creation of a number of new private banks that were poorly managed and served primarily to generate funds for the business activities of their owners. Further adding to the difficulties of the banking sector, corruption and government interference in lending was widespread.

Following the crisis, the government embarked on massive structural reforms privatizing and liquidating loss-making state-owned enterprises. The government also withdrew from the private credit market and privatized all state-owned banks, in most cases selling them to foreign banks. By the time of the survey in 2008, more than 90 percent of Bulgarian banks had been owned and operated by foreign banks for several years. The change in ownership and improved environment had led to substantial investment in banking services and generated a network of branch locations throughout the country. Various financial services such as mortgages, credit for small firms, a range of saving accounts, electronic payments, and personal and business lines of credit had been introduced. Further, prudential supervision and regulation had strengthened substantially. In addition, a transparent and fairly generous deposit insurance system had been implemented.

In the broader macroeconomic context, in 1997 Bulgaria introduced a currency board with a peg to the German mark and later to the euro. Within months, the new currency board lowered inflation to single digits. Economic growth also accelerated. Bulgaria experienced strong annual growth from the time it ended the largest structural reforms around 2000. At the time of the survey, there were no indications of economic slowdown or risks in the banking

\footnotetext{
${ }^{2}$ Although eventually depositors were allowed access to their deposits, their real value had been erased by the sharp inflation and currency depreciation.
} 
system. The percentage of loans considered "non-standard" was well below 5 percent. Entry into the EU and NATO provided assurance to foreign investors who poured in significant amount of funds.

Bulgaria continues to have a high level of corruption, weak governance, and a low level of income. Yet, objectively, the fundamental reasons for the 1996 banking crisis had been largely resolved well in advance of May 2008, when the survey was carried out. At the time of the survey, it was also months before the global financial crisis began. When the crisis started, Bulgaria's banks came under pressure to raise liquidity but they continued to provide a full range of services and stabilized within months without direct government intervention.

\section{The Formation of Expectations}

Economic theory has long recognized that past events can affect future expectations. As noted earlier, Cagan (1965) modeled the expectations of the future rate of loss on deposits as depending on some average of the past experience of losses. We extend this type of expectations modeling by proposing that individual experiences of a past event may differ causing them to vary in their influence. ${ }^{3}$ When an individual is directly and negatively affected by a past event, it is reasonable to expect that the memory of the event will be stronger and that this past event will be weighted more heavily in forming expectations. For example, a person who had recently been involved in a traffic accident at a particular intersection will likely have a higher assessment of the danger of this intersection, and be more cautious, than another person who had merely read about the accident in a newspaper account. ${ }^{4}$

The influence of such an experience on expectations may diminish over time, especially if the structures associated with the event change. Returning to our victim of a traffic accident, if a new traffic light is installed in the intersection, the individual may reduce his assessment of its danger. In our case, in Bulgaria, while many people suffered losses in the 1996 banking crisis,

\footnotetext{
${ }^{3}$ Akerloff and Schiller (2009), in discussing the causes of the run on banks of the 1890's Depression, describe stories of earlier bank runs forming a "social memory" among the population. This social memory facilitated the development of an instinct to avoid losses when "something did not look right" by withdrawing funds. Here, rather than an indirect social memory, we focus on individual memories formed from direct experiences.

${ }^{4}$ An assumption that negative experiences affect behavior seems reasonable as it is also used in the psychology literature. For example, an interesting stream of research in experimental psychology examines the effects of planting false memories into subjects. Bernstein (2009) notes the basic premise: "It seemed natural to assume that if a person had a bad experience with some object, then that person might avoid that object later." One study shows that individuals are willing to pay less for a Disney Pluto souvenir after the implantatation of a false memory of a negative experience as a child with the Pluto character at Disneyland (Berkowitz, et al, 2008).
} 
economic structures have changed drastically in recent years. Past events such as the 1996 banking crisis may no longer be perceived as relevant when forming expectations using all available information.

To formalize this, we assume individuals form their expectations of the future using their understanding of both past events and current economic conditions, including any changes in economic structures (Sheffrin, 1996). With no information costs, individuals would use all available information. However, analyzing information is costly and the extent to which individuals search for and process information about changing economic structures depends on the marginal cost and perceived marginal gain of engaging in this activity. Feige and Pierce (1976) refer to this as "economically rational expectations." The processing of information, particularly of new economic structures, may be affected by a number of factors, including the cost of accessing information, levels of human capital that reflect an individual's ability to process information, relative wealth that raises the gain from collecting information, etc. As individuals face different costs and expected gains, they may differ in the extent to which they gather and assess information. This gives rise to heterogeneity in terms of expectations formation that has been investigated by Feige and Pierce (1976), Haltiwanger and Waldman (1985), Branch (2004), Sethi and Franke (1995) and others.

We operationalize this idea of heterogeneity by dividing the survey respondents into two groups. "Naïve" agents have less information as a result of either relatively higher costs or lower expected benefits which reduces their information processing activity (IPA). They depend more on past events, particularly past experience, in forming their expectations. "Sophisticated" agents are more motivated to collect and interpret information, i.e. have higher IPA. Having a better understanding of current economic conditions and structures, they rely less on past experiences in forming their expectations,. Thus in our simple model, naïve agents weigh past experiences more heavily than sophisticated agents in their expectations formation. ${ }^{5}$

A differential effect of the 1996 crisis on the expectations of different groups of people is not a foregone conclusion. It may be that some kind of social memory rather than individual experiences determine the effect of past events on expectations. In this case individual

\footnotetext{
${ }^{5}$ We adopt Haltiwanger and Waldman's terms of "naïve" and "sophisticated" for convenience. Although we utilize a number of variables to separate respondents into the two groups, we view the differences to reflect varying costs and benefits of analyzing information and not the character of individuals assigned to one group or the other.
} 
experiences should have no differential effect. It could be the case that informed individuals continue to form their expectations based on the past crisis. Despite recognition of a changed economic environment, the informed could maintain the view that if a crisis happened before it is likely to happen again. Similarly, the less informed individuals might ignore or might have forgotten their experience from 12 years ago. Given these uncertainties, whether and how the past crisis in Bulgaria continues to affect expectations across different groups of individuals is an empirical question.

\section{Survey Data and Empirical Methodology}

Our data are taken from a national survey of households carried out in May 2008. The survey polled 1000 households, a standard sample size for national surveys of Bulgaria's population of 8 million. The sampling ensured representativeness with respect to demographics such as income, place of residence, education, and age. The data were collected by professional interviewers at the residence of each household. The survey project was conducted and supervised by an established Bulgarian polling agency, Vitosha Research. It included questions on the banking system that are used in this paper as well as a range of other questions on social and political topics. ${ }^{6}$ The question about expectations of a banking crisis was formulated as follows:

"In your opinion, how likely is it that the Bulgarian banking system will experience a crisis with several banks collapsing and depositors losing some of their savings during the next 6 months/1 year/5 years?"7

Table I reveals doubts among the respondents in the stability of the banking system. About 13 percent of the respondents believed that a banking crisis was likely or very likely (categories 1 and 2) even at the 6 months horizon. Confidence in the stability of the banking system diminishes the longer the time horizon. Twenty four percent of respondents believed that a

\footnotetext{
${ }^{6}$ The survey documentations along with the data are available from the authors.

${ }^{7}$ The question goes to some length to detail the consequences of a banking crisis. This formulation was preferred by the polling agency in lieu of a shorter formulation, such as, "In your opinion, how likely is it that the Bulgarian banking system will experience a crisis?" to make sure that respondents interpreted the term banking crisis in the same way. This has been the preferred approach in national household and consumer surveys where a large number of the sampled individuals are not experts on economics.
} 
banking crisis is likely or very likely at the five year horizon. At that horizon, only about a third of the respondents believed that a banking crisis was unlikely or very unlikely (categories 4 and 5). The survey also inquired about experiences during the 1996 crisis:

“Did you or members of your household lose money during the 1996 crisis?”

Respondents could answer: 1) we lost a large amount; 2) we lost some money; 3) we didn't lose anything; or 4) I don't know. Table II shows that well over 40 percent of the respondents reported experiencing a loss with over $10 \%$ experiencing a large loss.

The dependent variable used in all estimations is based on the question about expectations of a banking crisis. It is constructed as a dummy variable equal to 1 for responses of high and very high likelihood of a crisis (categories 1 and 2), and zero otherwise. We call this variable CRISIS. We estimate the models using the probit methodology with Huber/White robust standard errors. To facilitate the interpretation of the results, we report the marginal effects instead of the estimated probit coefficients so that we can discuss not only the direction of the effects but also their sizes. ${ }^{8}$

Our independent variable of primary interest is a measure of past experience and is based on the question about losses during the 1996 crisis. We construct a dummy variable that takes the value 1 for "some loss" and "lost a lot" and zero otherwise. We call this variable LOSS. We also report estimates where we distinguish between losses with different magnitude, i.e. between respondents who lost some money (SOME LOSS) and respondents who lost a lot (LOST A LOT). Hence, our empirical specification is as follows,

$$
\operatorname{Pr}\left(\text { CRISIS }_{\mathrm{i}}\right)=\varphi\left(\alpha+\beta \text { LOSS }_{\mathrm{i}}+\gamma \mathrm{X}_{\mathrm{i}}\right)+\mathrm{u}_{\mathrm{i}}
$$

where $\mathrm{i}$ indexes the individual respondents to the survey, $\mathrm{X}_{\mathrm{i}}$ is a set of control variables and $\mathrm{u}_{\mathrm{i}}$ is a random term. We expect to find $\beta>0$. Our benchmark estimation includes the following control variables: AGE in years; EDUCATION measured as a dummy variable taking the value

\footnotetext{
${ }^{8}$ An ordered probit model that uses all categories of the crisis expectations instead of the dummy variable yields the same results. We opted to use a simpler dependent variable and probit to make the interpretation of the coefficients more straightforward.
} 
1 for respondents with university education, college or post-graduate education, and 0 otherwise ${ }^{9}$; INCOME reported in local currency; and FEMALE equal to 1 for female respondents and 0 otherwise. Appendix 1 summarizes all survey questions used in the paper and Appendix 2 provides summary statistics.

Our discussion in the theory section suggests that the expectations of respondents who engage in more information processing activity (IPA) to acquire knowledge about the economy will be affected less, if at all, by previous losses. Therefore, we also estimate the following two equations:

$$
\begin{aligned}
& \operatorname{Pr}\left(\text { CRISIS }_{\mathrm{i}} \mid \text { IPA } \leq \text { IPA }^{*}\right)=\varphi\left(\alpha_{\mathrm{j}}+\beta_{\mathrm{j}} \text { LOSS }_{\mathrm{i}}+\gamma_{\mathrm{j}} \mathrm{X}_{\mathrm{i}}\right)+\mathrm{u}_{\mathrm{i}} \\
& \operatorname{Pr}\left(\text { CRISIS }_{\mathrm{i}} \mid \text { IPA }^{\prime} \text { IPA }^{*}\right)=\varphi\left(\alpha_{\mathrm{k}}+\beta_{\mathrm{k}} \text { LOSS }_{\mathrm{i}}+\gamma_{\mathrm{k}} \mathrm{X}_{\mathrm{i}}\right)+\mathrm{u}_{\mathrm{i}}
\end{aligned}
$$

where IPA > IPA* indicates an assessment that the returns from acquiring knowledge about the economy exceeds a given threshold and, respectively, IPA $\leq$ IPA* indicates that costs are relatively high compared to the gains from knowledge acquisition. Our hypotheses are $\beta_{\mathrm{j}}>0$ and $\beta_{\mathrm{k}}=0$. Estimating two separate equations as opposed to one equation with IPA interacted with LOSS allows for the possibility that the two subsamples are structurally different, yielding more reliable estimates.

We use three variables to distinguish between more informed and less informed individuals and to split the sample to separately estimate equations (2) and (3). First, we use EDUCATION to proxy for individuals' cost of staying informed about the economy. While more education does not necessarily imply better knowledge about the economy, more educated respondents are likely to face lower costs to collecting and analyzing information from the media and other information sources that provide such information. We estimate equation (3) for respondents with post-high school education and equation (2) for those with high school or less. Second, we use INCOME to proxy for peoples' motivation to stay informed. People with higher income might have greater savings and would therefore be motivated to keep track of economic developments. We split the sample around the median income bracket and, again, estimate equations (2) and (3). Third, we use the answers to the following question:

\footnotetext{
${ }^{9}$ We obtain similar effects with alternative education variables separating holders of high school diplomas from those with university degrees and people with less than high school education.
} 
"Inflation in Bulgaria has been below 15\% for the past 5 years."

to construct the variable INFORMED which equals 1 for respondents who agreed or strongly agreed with that statement, and 0 otherwise. Respondents who agreed or strongly agreed are considered informed as the statement is factually correct. The survey results indicate that only a quarter of the respondents were informed about past inflation in the country, with the vast majority answering they could not give an answer. Again, we split the sample according to these responses and separately estimate equations (2) and (3).

\section{Empirical Results}

The estimations in Table III show that losses during the 1996 crisis affect expectations. The LOSS variable is positive and statistically significant at all time horizons. People who reported a loss in 1996 were 6 percentage points more likely to expect a new crisis in the next six months compared to people who had no losses, 8 percent more likely during the next 1 year and 11 percent more likely in the next five years. The effect of losses on expectations is even stronger if we differentiate between people who experienced some loss and those who experienced a large loss. Respondents who lost a large amount in 1996 were 23 percentage points more likely to expect a crisis in the next five years compared to respondents who did not lose anything. They were also 16 percentage points more likely to expect a crisis compared to respondents who lost a smaller amount. ${ }^{10}$ Therefore, the magnitude of the loss makes a substantial difference. This underlines the importance of personal experiences: expectations are influenced by the extent to which an individual was affected by the crisis, and not simply by the awareness that a crisis happened. Looking at the demographic variables, age, education, and gender have no statistically significant effects on expectations. Only income is statistically significant at the six months horizon, with higher income associated with a lower likelihood of a crisis, but the effect disappears over longer time horizons.

\section{Third Underlying Factors}

\footnotetext{
${ }^{10}$ The difference $0.234-0.078=0.156$ is statistically significant.
} 
While straightforward at first glance, estimating equation (1) presents important challenges that have to be resolved before we can be certain of the robustness of the estimated relationships. First, it is possible that the respondents' stated likelihood of a banking crisis and their recollection of past losses are driven by a third underlying factor. Respondents who possess greater knowledge about the economy might recognize that a banking crisis is less likely in the current environment, but they might also have been able to avert losses during the 1996 crisis by anticipating it. It would then be the extent of their information about the economy that contributes to both a lower reported likelihood of a future banking crisis and a lower reported loss. To account for that possibility, in addition to EDUCATION and INCOME which proxy for peoples' ability and motivation to stay informed, we also include the variable INFORMED as an additional control variable in Table IV. The results show that LOSS remains positive and statistically significant.

Furthermore, expectations might be driven by people's risk attitudes. Although in principle how an individual assesses the likelihood of an event (expectations formation) should be independent from that individual's risk attitudes, it is possible that people who are less tolerant to risk might tend to magnify the likelihood of negative events. They might also be more likely to magnify how negatively they were affected in 1996. Conversely, people who are more tolerant to risk might downplay their losses in 1996 as well as the likelihood of a new crisis. Not accounting for risk attitudes could therefore produce biased estimates on the LOSS variable. To address this potential problem, we include a measure of risk attitudes based on respondents' answers to the following question:

"Suppose that I give you 1000 leva. You can keep the money or you can choose to participate in a game. I will throw a coin. If "heads" you win 1500 leva, if "tails" you win 900 leva. Do you prefer to play the game or to keep the 1000 leva?"11

We constructed a dummy variable Risk that equals 1 for respondents who prefer to play the game and 0 otherwise. Note that only 28 percent of the respondents preferred to play the game despite the heavy odds in their favor. The results in Table IV show that the LOSS variable remains statistically significant while RISK and INFORMED are not statistically significant.

${ }^{11} 1000$ leva is equivalent to about two average monthly salaries. 


\section{Instrumental Variables Estimation}

A second concern about estimating equation (1) is that of reverse causality, i.e. respondents who expect a crisis might also report a loss. In a strict sense, reverse causality is unlikely as the loss question refers to an event well into the past that should not influence expectations today. However, respondents who expect a crisis might incorrectly recall that they had experienced a loss, possibly to rationalize their expectations. We doubt that the respondents were making this link since the two questions were separated in the survey by 24 other questions (that have little relevance to the topic of this paper). Yet, checking for reverse causality with the use of instrumental variables can give us more confidence in the results.

The use of instrumental variables helps address one additional potential problem. It is reasonable to suppose that people do not have a good recollection of what happened 12 years ago. Some people might magnify the severity of their experiences while others might tend to forget easily. Memory bias has been recorded in various surveys asking respondents to recall past events. ${ }^{12}$ The 1996 crisis is an important event in Bulgaria's transition history and it is unlikely that people have forgotten it. Politicians, economists and the media make frequent references to these times. Yet, these reminders might also magnify people's beliefs about their past losses.

We use two variables as instruments. One of them makes use of the minority status of some of Bulgaria's citizens. About 6 percent of the population belongs to the Roma minority. As elsewhere, minorities have less access to financial services, all else equal. ${ }^{13}$ This is especially true of the Roma minorities that are typically not well integrated in East European countries. This makes minority status useful in our case because, with less participation in formal banking, minority citizens might have been less exposed to loss during the banking crisis. Yet, whether or not a citizen belongs to a minority group should not affect their expectations of a banking crisis directly.

\footnotetext{
${ }^{12}$ See Gilbert (2007) for an excellent account of how memory can be biased in forming expectations about how choices can affect one's happiness.

${ }^{13}$ Assessing the 2001 Survey on Income and Program Participation, a nationally representative sample of US households, Osili and Paulson (2009) find that, all else equal, while 67 percent of the native born household have checking accounts, only 59 percent of black native born households have savings accounts.
} 
The second variable we use as an instrument is a dummy variable that equals 1 for respondents who are less than 32 years old, and zero otherwise. Respondents who were less than 32 years old at the time of the survey were younger than 20 when the banking crisis occurred. They are therefore less likely to have had funds in a banking account and to report losses than older respondents while, at the same time, their age does not influence their expectations. More precisely, the crisis could affect the expectations of younger respondents but only through their experiences with the 1996 crisis. This makes the variable suitable as an instrument. ${ }^{14}$

The instrumental variables estimations are reported in Table V. We use a two stage OLS estimator with robust standard errors as opposed to a probit model with an endogenous explanatory variable. This creates the potential for predicted values falling outside the unit interval. However, the procedure allows us to instrument for a dichotomous explanatory variable (LOSS) whereas standard estimation procedures are applicable only for continuous endogenous explanatory variables. Furthermore, only 4 out of the 805 observations used in the estimations fall outside the $[0,1]$ interval.

The results in Table V show that LOSS is positive and statistically significant across all forecast horizons. We report three tests that validate the choice of instruments. The null hypothesis of the Kleibergen-Paap rk LM Test is that the endogenous regressor (LOSS) is not identified by the instruments. The null was rejected at the 1 percent level providing evidence that the excluded instruments explain the endogenous variable. This is confirmed by the F-statistic that is also significant at the 1 percent level. The F-statistic also exceeds the rule of thumb threshold $(\mathrm{F}>10)$ proposed by Staiger and Stock (1997). The null hypothesis of the Hansen $\mathbf{J}$ Test is that the excluded instruments are uncorrelated with the error term in the stage two equation. We fail to reject the null of the Hansen $\mathrm{J}$ Test indicating that the instruments are uncorrelated with the residuals in the stage two equation. ${ }^{15}$

Based on the estimations reported above, we can conclude that experiencing a loss during a banking crisis more than a decade ago significantly increases the expectations of a new crisis.

\footnotetext{
${ }^{14}$ Note that the question about losses refers to personal as well as household losses. Therefore, many young respondents reported losses but as a smaller percent compared to older respondents. In other words, the variable does not predict perfectly the likelihood of a loss, making it suitable as an instrument.

${ }^{15}$ We obtained similar results after adding a third instrumental variable: the place of residence of a respondent. The variable was used on the principle that residents of the capital Sofia have greater access to financial services because many bank branches are located there. In contrast, residents of rural areas have substantially less access to banking services. This affects their losses during a crisis but not necessarily their expectations of a new crisis.
} 


\section{Sophisticated and Naïve Individuals}

Next, we estimate equations (2) and (3) after splitting the sample into two groups using the responses to the question about past inflation, then income and then education. The results, reported in Table VI indicate that experiences of a loss in the 1996 crisis do not affect the expectations of the more "sophisticated" respondents using any of the three criteria associated with information processing activity. In contrast, for the less informed, "naïve" groups, the prior experience of a loss enters significantly in the regressions explaining the expectations whether the sample split is from education, income or responses to the question on inflation. The results are consistent with our hypothesis that more sophisticated actors can process information about changing structures and adapt their expectations accordingly while expectations of relatively naïve actors are more likely to rely on past, particularly negative, experiences. ${ }^{16}$ The results are robust to changes in the sample dividing point in both directions for both education and income.

\section{Concluding Remarks}

The results presented in this paper show that prior negative experiences with a banking crisis elevate expectations of a new crisis and that this effect persists for a long time period, twelve years in our study. This result is robust to various econometric specifications and robustness tests.

Although the results are based on a survey from Bulgaria, we suppose that the same effect would be observed in other countries where people lost money during a banking crisis. Yet, Bulgaria might be different. Its rapid economic and political transformation might loosen the ties between past and present as the past is less indicative of the future. On the other hand, its short history with capitalism gives people a limited number of observations about how the economy functions. In this case, a banking crisis might be more influential on expectations compared to other countries where the social and personal memories contain a number of ups

\footnotetext{
${ }^{16}$ Using three different variables to separate between more and less informed individuals provides a useful robustness test. It is conceivable that people who lost money in 1996 feel more motivated to stay informed about the economy. Then, the crisis would affect not only expectations but also the variable INFORMED. Losing money during the crisis might also have affected some people's long-term income level. These hypotheses are not supported by our data - people who lost money in 1996 are not more likely to be informed about the economy and don't have lower (or higher) incomes. Yet, using education as an additional variable gives us further confidence in the results as the crisis is unlikely to affect peoples' long-term education levels.
} 
and downs. We hope that future studies with data from other countries can shed light on the broader relevance of our findings.

The important role of financial development in economic growth has come to be accepted since the pioneering work of King and Levine (1993). Guiso, Sapienza and Zingales (2004) and Knack and Keefer (1997), among others, show that trust is an essential determinant of financial development. Incomplete trust leads to lower than optimal levels of financial intermediation, with broader effects on savings and investment behavior. Yet most studies of banking crisis focus only on resolving causality and on the short-term output contractions. The question of long-term negative effects has received very little attention. In one study, IADB, 2004, the authors find that a banking crisis reduces long-term economic growth by about 1 percentage point. While the paper doesn't investigate the channels of this effect, our results suggest that a crisis' persistent effect on expectations of future crisis may affect long-term decision-making, producing a drag on economic growth for a number of years after the crisis. Based on the IADB study and our analysis using the Bulgarian survey data, we believe that investigating the longterm consequences of banking crises is a promising line of research.

Our results indicate that policy makers have an opportunity to influence the long term effects of a banking crisis. Structural reforms to change the economy's operations can reduce the persistent effect of a past crisis on expectations. But, as our results show, this effect may be largely limited to a more "sophisticated" segment of the population who can recognize that the drivers of earlier crises are no longer a major issue. Efforts of policymakers to encourage individuals to adapt their expectations in response to an improved economic environment following a crisis face a significant challenge and should take into account different segments of the population. The most likely to change their expectations are those who did not experience a personal loss and those who are relatively well informed. Efforts to decrease the costs of becoming informed, for example through public information campaigns, should accompany economic reform to increase that portion of the population who recognize changed economic circumstances and the lower relevance of past experiences. 


\section{Bibliography}

Akerloff, George and Robert Schiller (2009), Animal Spirits, Princeton: Princeton University Press.

Berkowitz, Shari, Cara Laney, Erin Morris, Maryanne Garry and Elizabeth Loftus (2008), "Pluto Behaving Badly: False Beliefs and their Consequences," American Journal of Psychology 121 (4), 643-660.

Berlemann, Michael, Kalin Hristov and Nikolay Nenovsky (2002), "Lending of Last Resort, Moral Hazard and Twin Crises: Lessons from the Bulgarian Financial Crisis 1996/199," William Davidson Working Paper Number 464 (May).

Bernstein, Daniel and Elizabeth Loftus (2009), "The Consequences of False Memories for Food Preferences and Choices," Perspectives on Psychological Science, 4 (2), 135-139.

Branch, William (2004), "The Theory of Rationally Heterogeneous Expectations: Evidence from Survey Data on Inflation Expectations.” The Economic Journal, 114, 592-621.

Bulgarian National Bank, Annual Report, various years.

Cagan, Philip, (1965), The Demand for Currency Relative to Total Money Supply, New York: NBER Occasional Paper 62.

Calvo, Guillermo (1986), “Temporary Stabilization: Predetermined Exchange Rates.” Journal of Political Economy 94, 1319-1329.

Dobrinsky, Rumen (2000), “The Transition Crisis in Bulgaria," Cambridge Journal of Economics, 24, 581-602.

Feige, Edgar, and Douglas Pierce (1976), "Economically Rational Expectations: Are Innovations in the Rate of Inflation Independent of Innovations in Measures of Monetary and Fiscal Policy?" Journal of Political Economy 84, 499-522.

Guiso, Luigi, Paola Sapienza and Luigi Zingales (2004), "The Role of Social Capital in Financial Development," American Economic Review, 94 (3), 526-556.

IABD, Inter-American Development Bank (2004), Unlocking Credit: The Quest for Deep and Stable Bank Lending, 2005 Report on Economic and Social Progress in Latin America, Washington DC: Inter-American Development Bank and Johns Hopkins Press.

King, Robert and Ross Levine (1993), "Finance and Growth: Schumpeter Might Be Right," Quarterly Journal Economics, 108(3), 717-37. 
Knack, Stephen and Phillip Keifer (1997), "Does Social Capital Have an Economic Payoff?" Quarterly Journal of Economics 112, 1251-1289.

Haltiwanger, John and Michael Waldman (1985), "Rational Expectations and the Limits of Rationality: An Analysis of Heterogeneity," The American Economic Review, 75 (3), 326-340.

Mankiw, Gregory and Ricardo Reis (2002), "Sticky Information versus Sticky Prices: A Proposal to Replace the New Keynesian Philips Curve, “ Quarterly Journal of Economics, $117(4), 1295-1328$.

Melvin, Michael, Fenske, K. (1992), "Dollarization and Monetary Reform: Evidence from the Cochabamba Region of Bolivia." Revista de Analisis Economico 7(1), 127-138.

Sargent, Thomas J. (1982), The ends of four big inflations, in Inflation: Causes and Effects, R. E. Hall, ed. (University of Chicago Press, Chicago).

Sethi, Rajiv and Reiner Franke (1995), Behavioral heterogeneity under evolutionary pressure: Macroeconomic implications of costly optimization, The Economic Journal, 105, 583600 .

Sheffrin, Steven (1996), Rational Expectations, 2nd ed., Cambridge University Press.

Staiger, D. and J.H. Stock (1997), "Instrumental Variables Regression with Weak Instruments,” Econometrica, 65, 557 - 586. 
Appendix 1. Variables and survey questions used in the empirical analysis.

\begin{tabular}{|c|c|c|}
\hline & Survey question & Definition of variable \\
\hline CRISIS & $\begin{array}{l}\text { "In your opinion, how likely is it that } \\
\text { the Bulgarian banking system will } \\
\text { experience a crisis with several banks } \\
\text { collapsing and depositors losing some } \\
\text { of their savings during the next } 6 \\
\text { months } 1 \text { year } 5 \text { years?" } \\
1 \text { = "Very likely" } \\
\ldots \\
5 \text { = "Very unlikely" }\end{array}$ & $\begin{array}{l}1 \text { for very likely and likely (answers } 1 \\
\text { and 2), } 0 \text { otherwise }\end{array}$ \\
\hline $\begin{array}{l}\text { LOSS/ } \\
\text { LOST_A_LOT/ } \\
\text { LOST_SOME/ }\end{array}$ & $\begin{array}{l}\text { "Did you or members of your household } \\
\text { lose money during the } 1996 \text { crisis?" } \\
1=\text { "We lost a large amount" } \\
2 \text { = "We lost some money" } \\
3 \text { = "We did not lose anything" }\end{array}$ & $\begin{array}{l}1 \text { if a respondent reported a loss } \\
\text { (answers } 1 \text { and 2), } 0 \text { otherwise/ } \\
1 \text { for large loss (answer 1), } 0 \text { otherwise/ } \\
1 \text { for lost some (answer 2), } 0 \text { otherwise/ }\end{array}$ \\
\hline EDUCATION & $\begin{array}{l}1=\text { "Elementary or no education" } \\
2=\text { "Primary" } \\
3=\text { "Secondary" } \\
4=\text { "College" } \\
5=\text { "Post-graduate degree" }\end{array}$ & $\begin{array}{l}1 \text { if college or post-graduate degree } \\
\text { (answers } 4 \text { and 5), } 0 \text { otherwise }\end{array}$ \\
\hline INCOME & $\begin{array}{l}\text { Total household income from all } \\
\text { sources: choose from income brackets } \\
\text { staring at } 0 \text { leva, at } 100 \text { leva intervals: } \\
1=\text { " } 0-100 \text { leva" } \\
2=\text { "101-200 leva" } \\
\ldots\end{array}$ & $\begin{array}{l}\text { Income categories (monthly) reported } \\
\text { by respondents, using the mid-value of } \\
\text { each interval. }\end{array}$ \\
\hline AGE & Age in years. & Age in years. \\
\hline FEMALE & Male / female & 1 for female, 0 for male \\
\hline INFORMED & $\begin{array}{l}\text { "Inflation in Bulgaria has been below } \\
15 \% \text { for the past } 5 \text { years." } \\
1=\text { "Strongly agree" } \\
\ldots \\
5=\text { "Strongly disagree" }\end{array}$ & $\begin{array}{l}1 \text { for strongly agree and agree (answers } \\
1 \text { and 2), } 0 \text { otherwise }\end{array}$ \\
\hline RISK & $\begin{array}{l}\text { "Suppose that I give you } 1000 \text { leva. You } \\
\text { can keep the money or you can choose } \\
\text { to participate in a game. I will throw a } \\
\text { coin. If "heads" you win } 1500 \text { leva, if } \\
\text { "tails" you win } 900 \text { leva. Do you prefer } \\
\text { to play the game or to keep the } 1000\end{array}$ & $\begin{array}{l}1 \text { if prefers to play the game, } 0 \\
\text { otherwise }\end{array}$ \\
\hline
\end{tabular}


\begin{tabular}{|l|l|l|}
\hline & leva?” & \\
\hline
\end{tabular} 
Appendix 2. Summary statistics

\begin{tabular}{|c|c|c|c|c|c|c|c|c|c|c|c|c|}
\hline & Crisis_6m & $\begin{array}{l}\text { Crisis_ } \\
12 \mathrm{~m}\end{array}$ & Crisis_5y & Loss & Lost a lot & Some loss & Education & Income & Age & Female & Informed & Risk \\
\hline Mean & 0.13 & 0.19 & 0.22 & 0.46 & 0.11 & 0.34 & 0.25 & 559 & 51.89 & 0.59 & 0.25 & 0.28 \\
\hline St. deviation & 0.33 & 0.39 & 0.41 & 0.49 & 0.31 & 0.47 & 0.43 & 516 & 16.21 & 0.49 & 0.43 & 0.45 \\
\hline Minimum & 0 & 0 & 0 & 0 & 0 & 0 & 0 & 50 & 18 & 0 & 0 & 0 \\
\hline Maximum & 1 & 1 & 1 & 1 & 1 & 1 & 1 & 5500 & 89 & 1 & 1 & 1 \\
\hline \multicolumn{13}{|l|}{ Correlations } \\
\hline Crisis_6m & 1.00 & & & & & & & & & & & \\
\hline Crisis_12m & $0.70 *$ & 1.00 & & & & & & & & & & \\
\hline Crisis_5y & $0.45^{*}$ & $0.62 *$ & 1.00 & & & & & & & & & \\
\hline Loss & $0.08^{*}$ & $0.10^{*}$ & $0.12 *$ & 1.00 & & & & & & & & \\
\hline Some loss & 0.05 & 0.06 & 0.03 & $0.77 *$ & $-0.26^{*}$ & 1.00 & & & & & & \\
\hline Higher & 0.03 & 0.06 & $0.06^{*}$ & $0.07 *$ & 0.03 & 0.06 & 1.00 & & & & & \\
\hline Income & $-0.06^{*}$ & 0.01 & 0.04 & 0.03 & 0.02 & 0.01 & $0.27 *$ & 1.00 & & & & \\
\hline Age & 0.06 & 0.03 & -0.01 & 0.06 & 0.05 & 0.03 & $-0.07 *$ & $-0.49^{*}$ & 1.00 & & & \\
\hline Female & 0.00 & -0.03 & 0.01 & -0.01 & -0.03 & 0.01 & 0.05 & -0.05 & $-0.06^{*}$ & 1.00 & & \\
\hline Informed & 0.00 & 0.03 & 0.00 & $-0.07 *$ & -0.04 & -0.05 & 0.05 & $0.16^{*}$ & -0.05 & -0.04 & 1.00 & \\
\hline Risk & -0.05 & -0.05 & -0.03 & 0.02 & -0.02 & 0.03 & $0.14^{*}$ & $0.33^{*}$ & $-0.28^{*}$ & -0.03 & $0.08^{*}$ & 1.00 \\
\hline
\end{tabular}

Note: * indicates statistical significance at the 5 percent level. 


\section{Table I}

Survey responses on banking crisis expectations.

(Percent respondents in each category)

"In your opinion, how likely is it that the Bulgarian banking system will experience a crisis with several banks collapsing and depositors losing some of their savings?"

\begin{tabular}{rccc}
\hline & 6 months & 1 year & 5 years \\
\hline Very likely 1 & 6.7 & 9.6 & 13.9 \\
3 & 6.5 & 9.7 & 8.9 \\
4 & 18.0 & 17.9 & 14.5 \\
Very unlikely 5 & 31.0 & 16.5 & 12.6 \\
Don't know/No Answer & 19.9 & 24.9 & 18.5 \\
Total & 100.0 & 21.4 & 31.6 \\
\hline
\end{tabular}




\section{Table II}

Survey responses on experience of the 1996 banking crisis.

(Percent respondents in each category)

"Did you or members of your household lose money during the 1996 crisis?"

\begin{tabular}{lc}
\hline Lost a large amount & 11.1 \\
Lost some amount & 31.1 \\
We did not lose anything & 48.8 \\
Don't know/No Answer & 9.0 \\
Total & 100.0 \\
\hline
\end{tabular}


Table III

Losses during a banking crisis and expectations.

Dependent variable: 1 if respondent believes that a banking crisis is likely or very likely, 0 otherwise. Probit analysis.

\begin{tabular}{|c|c|c|c|c|c|c|}
\hline & 6 months & 1 year & 5 years & 6 months & 1 year & 5 years \\
\hline Loss & $\begin{array}{l}0.056^{* *} \\
(0.024)\end{array}$ & $\begin{array}{l}0.080 * * * \\
(0.028)\end{array}$ & $\begin{array}{l}0.115^{* * *} \\
(0.030)\end{array}$ & & & \\
\hline Some Loss & & & & $\begin{array}{l}0.055^{* *} \\
(0.028)\end{array}$ & $\begin{array}{l}0.077 * * \\
(0.033)\end{array}$ & $\begin{array}{l}0.078 * * \\
(0.035)\end{array}$ \\
\hline Lost a lot & & & & $\begin{array}{c}0.074 * \\
(0.043)\end{array}$ & $\begin{array}{l}0.103 * * \\
(0.049)\end{array}$ & $\begin{array}{c}0.234 * * * \\
(0.054)\end{array}$ \\
\hline Age & $\begin{array}{c}0.001 \\
(0.001)\end{array}$ & $\begin{array}{c}0.001 \\
(0.001)\end{array}$ & $\begin{array}{l}-0.001 \\
(0.001)\end{array}$ & $\begin{array}{c}0.001 \\
(0.001)\end{array}$ & $\begin{array}{c}0.001 \\
(0.001)\end{array}$ & $\begin{array}{l}-0.001 \\
(0.001)\end{array}$ \\
\hline Income & $\begin{array}{l}-0.076 * * \\
(0.033)\end{array}$ & $\begin{array}{l}-0.025 \\
(0.026)\end{array}$ & $\begin{array}{l}-0.023 \\
(0.028)\end{array}$ & $\begin{array}{l}-0.077^{* *} \\
(0.033)\end{array}$ & $\begin{array}{l}-0.026 \\
(0.027)\end{array}$ & $\begin{array}{l}-0.024 \\
(0.028)\end{array}$ \\
\hline Education & $\begin{array}{c}0.042 \\
(0.031)\end{array}$ & $\begin{array}{c}0.054 \\
(0.035)\end{array}$ & $\begin{array}{c}0.032 \\
(0.037)\end{array}$ & $\begin{array}{c}0.042 \\
(0.031)\end{array}$ & $\begin{array}{c}0.054 \\
(0.035)\end{array}$ & $\begin{array}{c}0.031 \\
(0.037)\end{array}$ \\
\hline Female & $\begin{array}{l}-0.011 \\
(0.024)\end{array}$ & $\begin{array}{l}-0.038 \\
(0.029)\end{array}$ & $\begin{array}{l}-0.001 \\
(0.031)\end{array}$ & $\begin{array}{l}-0.011 \\
(0.024)\end{array}$ & $\begin{array}{l}-0.038 \\
(0.029)\end{array}$ & $\begin{array}{c}0.001 \\
(0.031)\end{array}$ \\
\hline Chi 2(5) & $15.03 * * *$ & $14.01 * *$ & $15.78 * * *$ & & & \\
\hline Chi 2(6) & & & & $15.11 * *$ & $14.18 * *$ & $24.11 * * *$ \\
\hline Obs. & 805 & 805 & 805 & 805 & 805 & 805 \\
\hline
\end{tabular}

Note: Robust standard errors in parentheses. $* * *(* * *)$ indicates statistical significance at the $1(5,10)$ percent level. 
Robustness checks for additional underlying factors. Dependent variable: 1 if respondent believes that a banking crisis is likely or very likely, 0 otherwise. One year horizon. Probit analysis.

\begin{tabular}{|c|c|c|}
\hline & $\begin{array}{l}\text { Adding } \\
\text { "Informed" }\end{array}$ & $\begin{array}{l}\text { Adding } \\
\text { "Risk" }\end{array}$ \\
\hline Loss & $\begin{array}{l}0.082 * * * \\
(0.028)\end{array}$ & $\begin{array}{l}0.081 * * * \\
(0.028)\end{array}$ \\
\hline Age & $\begin{array}{c}0.001 \\
(0.001)\end{array}$ & $\begin{array}{c}0.001 \\
(0.001)\end{array}$ \\
\hline Income & $\begin{array}{l}-0.029 \\
(0.027)\end{array}$ & $\begin{array}{l}-0.018 \\
(0.028)\end{array}$ \\
\hline Education & $\begin{array}{c}0.053 \\
(0.035)\end{array}$ & $\begin{array}{c}0.056 \\
(0.036)\end{array}$ \\
\hline Female & $\begin{array}{l}-0.037 \\
(0.029)\end{array}$ & $\begin{array}{l}-0.039 \\
(0.029)\end{array}$ \\
\hline Informed & $\begin{array}{c}0.034 \\
(0.033)\end{array}$ & \\
\hline Risk & & $\begin{array}{l}-0.033 \\
(0.033)\end{array}$ \\
\hline $\begin{array}{l}\text { Chi 2(\# expl. variables) } \\
\text { Observations }\end{array}$ & $\begin{array}{l}14.99 * * \\
805\end{array}$ & $\begin{array}{l}14.97 * * \\
805\end{array}$ \\
\hline
\end{tabular}

Note: Robust standard errors in the parentheses. ${ }^{* * *}(* *, *)$ indicates statistical significance at the $1(5,10)$ percent level. 


\section{Table V}

Instrumental variables estimation.

\begin{tabular}{lccc} 
& $\begin{array}{c}\text { Six months } \\
\text { horizon }\end{array}$ & $\begin{array}{c}\text { One year } \\
\text { horizon }\end{array}$ & $\begin{array}{c}\text { Five years } \\
\text { horizon }\end{array}$ \\
\hline $\begin{array}{l}\text { Loss } \\
\text { predicted value from stage 1) }\end{array}$ & $0.365^{* * *}$ & $0.556^{* * *}$ & $0.659^{* * *}$ \\
& $(0.106)$ & $(0.133)$ & $(0.161)$ \\
Age & 0.001 & 0.001 & $0.002^{*}$ \\
& $(0.001)$ & $(0.001)$ & $(0.001)$ \\
& & & \\
Income & $-0.062^{* * *}$ & -0.041 & $-0.041^{* * *}$ \\
& $(0.021)$ & $(0.028)$ & $(0.032)$ \\
& & & \\
Education & 0.001 & 0.008 & 0.020 \\
& $(0.035)$ & $(0.044)$ & $(0.047)$ \\
Female & & & \\
& 0.003 & -0.014 & 0.027 \\
Observations & $(0.028)$ & $(0.034)$ & $(0.037)$ \\
F - Statistic & 805 & 805 & 805 \\
Prob $>$ F & $16.59^{* * *}$ & $16.59^{* * *}$ & $16.59^{* * *}$ \\
Kleibergen-Paap rk LM Statistic & 0.001 & 0.001 & 0.001 \\
Kleibergen-Paap rk LM p-value & $20.489^{* * *}$ & $20.489^{* * *}$ & $20.489^{* * *}$ \\
Hansen J statistic & 0.001 & 0.001 & 0.001 \\
Hansen J statistic p-value & 0.983 & 0.282 & 2.535 \\
\hline $\begin{array}{l}\text { Note: Robust standard errors in parentheses. ***(***) indicates statistical significance at the 1 } 1(5,10) \\
\text { percent level. }\end{array}$ & & & \\
& & &
\end{tabular}




\section{Table VI}

The expectations of "sophisticated" and "naïve" respondents.

Dependent variable: 1 if respondent believes that a banking crisis is likely or very likely, 0 otherwise. One year horizon.

Probit analysis.

Information about the economy

Income level Education level

\begin{tabular}{lcccccc}
\hline & $\begin{array}{c}\text { More } \\
\text { informed }\end{array}$ & $\begin{array}{c}\text { Less } \\
\text { informed }\end{array}$ & $\begin{array}{c}\text { Higher } \\
\text { income }\end{array}$ & $\begin{array}{c}\text { Lower } \\
\text { income }\end{array}$ & $\begin{array}{c}\text { More } \\
\text { education }\end{array}$ & $\begin{array}{c}\text { Less } \\
\text { education }\end{array}$ \\
Loss & 0.035 & $0.103^{* * *}$ & 0.026 & $0.115^{* * *}$ & 0.068 & $0.083^{* * *}$ \\
& $(0.057)$ & $(0.032)$ & $(0.045)$ & $(0.036)$ & $(0.061)$ & $(0.032)$ \\
Age & -0.001 & 0.001 & $0.003^{*}$ & 0.001 & 0.002 & 0.001 \\
& $(0.001)$ & $(0.001)$ & $(0.002)$ & $(0.001)$ & $(0.002)$ & $(0.001)$ \\
Income & $-0.077^{*}$ & -0.003 & $-0.086^{*}$ & 0.072 & -0.035 & -0.018 \\
& $(0.046)$ & $(0.036)$ & $(0.046)$ & $(0.165)$ & $(0.048)$ & $(0.031)$ \\
Education & $0.119 *$ & 0.019 & 0.044 & 0.052 & & \\
& $(0.068)$ & $(0.040)$ & $(0.049)$ & $(0.050)$ & & \\
Female & -0.054 & -0.029 & -0.011 & -0.055 & -0.055 & -0.032 \\
& $(0.057)$ & $(0.034)$ & $(0.046)$ & $(0.038)$ & $(0.067)$ & $(0.032)$ \\
Chi 2(5) & 5.82 & $12.82^{* *}$ & 7.00 & $15.62 * * *$ & 4.81 & $8.39 *$ \\
Obs. & 218 & 587 & 331 & 474 & 194 & 611 \\
\hline
\end{tabular}

Note: Robust standard errors in parentheses. ${ }^{* * *}(* * * *)$ indicates statistical significance at the $1(5,10)$ percent level. 


\section{DAVIDSON INSTITUTE WORKING PAPER SERIES - Most Recent Papers}

The entire Working Paper Series may be downloaded free of charge at: www.wdi.umich.edu

CURRENT AS OF $10 / 7 / 09$

\begin{tabular}{|c|c|c|}
\hline Publication & Authors & Date \\
\hline $\begin{array}{l}\text { No. 969: Once Bitten, Twice Shy: Experiences Of A Banking Crisis } \\
\text { And Expectations Of Future Crises }\end{array}$ & Shannon Mudd \& Neven Valev & Sept 2009 \\
\hline $\begin{array}{l}\text { No. 968: Monetary policy rules and inflation process in open emerging } \\
\text { economies: evidence for } 12 \text { new EU members }\end{array}$ & Bořek Vašíček & Sept 2009 \\
\hline $\begin{array}{l}\text { No. 967: Extending Likages Between Organizational Analysis And Social } \\
\text { Structure: A Case Study Of The Celebrity-Construction Of A Chinese } \\
\text { Marketplace }\end{array}$ & Mark Jacobs & Aug 2009 \\
\hline $\begin{array}{l}\text { No. 966: Chinese state's economic cooperation related investment: An } \\
\text { investigation of its direction and some implications for outward } \\
\text { investment }\end{array}$ & $\begin{array}{l}\text { Sumon Bhaumik and } \\
\text { Catherine Yap Co }\end{array}$ & Aug 2009 \\
\hline $\begin{array}{l}\text { No. 965: Capital inflows, household debt and the boom-bust cycle in } \\
\text { Estonia }\end{array}$ & $\begin{array}{l}\text { Zuzana Brixiova, Laura Vartia } \\
\text { and Andreas Worgotter }\end{array}$ & July 2009 \\
\hline No. 964: Labour Market Felxibility in Estonia: What More Can be Done? & Zuzana Brixiova & July 2009 \\
\hline $\begin{array}{l}\text { No. 963: Market Globalization by Firms from Emerging Markets \& Small } \\
\text { Countries: An Application of the Neoclassical Trade Model }\end{array}$ & Tamir Agmon & July 2009 \\
\hline $\begin{array}{l}\text { No. 962: Central Bank Communication and Exchange Rate Volatility: A } \\
\text { GARCH Analysis }\end{array}$ & $\begin{array}{l}\text { Roman Horvath and Radovan } \\
\text { Fiser }\end{array}$ & July 2009 \\
\hline $\begin{array}{l}\text { No. 961: On the influence of oil prices on stock markets: } \\
\text { Evidence from panel analysis in GCC countries. }\end{array}$ & $\begin{array}{l}\text { Christophe Rault and Mohamed } \\
\text { El Hedi Arouri }\end{array}$ & June 2009 \\
\hline $\begin{array}{l}\text { No. 960: Oil Prices \& Stock Markets: What Drives What in the Gulf } \\
\text { Corporation Council Countries? }\end{array}$ & $\begin{array}{l}\text { Christophe Rault and Mohamed } \\
\text { El Hedi Arouri } \\
\end{array}$ & June 2009 \\
\hline $\begin{array}{l}\text { No. 959: Trade Specialisation And Economic Convergence: } \\
\text { Evidence From Two Eastern European Countries }\end{array}$ & $\begin{array}{l}\text { Christophe Rault, Guglielmo } \\
\text { Caporale, Robert Sova \& } \\
\text { Anamaria Sova }\end{array}$ & June 2009 \\
\hline $\begin{array}{l}\text { No. 958: Inflation differentials in the Euro area and their determinants } \\
\text { - an empirical view }\end{array}$ & $\begin{array}{c}\text { Juan Ignacio Aldasoro \& Václav } \\
\text { Žd'árek }\end{array}$ & April 2009 \\
\hline No. 957: Infrastructure and growth: Empirical evidence & $\begin{array}{c}\text { Balazs Egert, Tomasz } \\
\text { Kozluk and Douglas Sutherland }\end{array}$ & April 2009 \\
\hline $\begin{array}{l}\text { No. 956: Infrastructure investment in network industries: The role of } \\
\text { incentive regulation and regulatory independence }\end{array}$ & Balazs Egert & April 2009 \\
\hline $\begin{array}{l}\text { No. 955: The impact of monetary and commodity fundamentals, macro } \\
\text { news and central bank communication on the exchange rate: } \\
\text { Evidence from South Africa }\end{array}$ & Balazs Egert & April 2009 \\
\hline $\begin{array}{l}\text { No. 954: "Family" ownership, tunneling and earnings management: } \\
\text { A review of the literature }\end{array}$ & $\begin{array}{l}\text { Sumon Bhaumik and Andros } \\
\text { Gregoriou }\end{array}$ & $\begin{array}{l}\text { March } \\
2009\end{array}$ \\
\hline $\begin{array}{l}\text { No. 953: Impact of Foreign Direct Investments on Industrial Productivity: } \\
\text { A Subnational Study of India }\end{array}$ & Krishna C. Vadlamannati & $\begin{array}{c}\text { March } \\
2009\end{array}$ \\
\hline $\begin{array}{l}\text { No. 952: Determinants of Exchange Rate Practices in the MENA } \\
\text { Countries: Some Further Empirical Results }\end{array}$ & Sfia, M. Daly and Mouley Sami & Jan 2009 \\
\hline No. 951: An Analytic Approach To Selecting A Nonprofit & $\begin{array}{l}\text { Andrés Ramírez and } \\
\text { Hakan Saraoglu }\end{array}$ & Jan 2009 \\
\hline $\begin{array}{l}\text { No. 950: Anthropometry of Love } \\
\text { Height and Gender Asymmetries in Interethnic Marriages }\end{array}$ & Michèle Belot and Jan Fidrmuc & Jan 2009 \\
\hline No. 949: Is THE COST OF LIVING IN RUSSIA REALLY THAT LOW? & Konstantin Gluschenko & Dec 2008 \\
\hline $\begin{array}{l}\text { No. 948: Banking Market Liberalization and Bank Performance: the Role } \\
\text { of Entry Modes }\end{array}$ & Ngoc-Anh Vo Thi & Jan 2009 \\
\hline $\begin{array}{l}\text { No. 947: The Monetary Union: The Decade Ahead. } \\
\text { The Case of Non-Member States }\end{array}$ & Daniel Daianu and Laurian Lungu & Jan 2009 \\
\hline
\end{tabular}

